\title{
The Textiles and Garments Sector: Moving Up the Value Chain
}

\author{
Naved Hamid", Ijaz Nabi ${ }^{* *}$, and Rafia Zafar ${ }^{* * *}$
}

\begin{abstract}
The textiles and garments (TEG) sector accounts for almost $50 \%$ of Pakistan's exports and is the largest component of manufacturing. TEG sector, because of recent favorable developments for the industry in Pakistan and the expected future changes in the international trade structure for the sector, has the potential to play an important role in expanding Pakistan's exports. In addition, garments manufacturing is the least energy and capital intensive industrial activity and thus resonates with Pakistan's resource endowment to generate economic growth and employment.

Garment manufacturers have tried to overcome the constraints arising from the energy shortages and adverse security and country risk perceptions by investing in power generation, upgrading IT, developing design and RED capability. Punjab Government's focus on garments as a central plank of its industrial strategy has also helped. However, this paper argues that for the sector to fully realize its potential, government policies that shape the incentive structure faced by the industry need to be re-aligned In this regard, the most important is Pakistan's import policies and customs procedures that discourage the import of materials such as synthetic yarn and fabric, technical textiles and specialized trimmings and accessories needed by exporters to move up the value chain, and a significant bump up in the growth trajectory will only take place if import policy and custom procedures are substantially reformed. This paper focuses on the following themes: First, structural changes and trends in TEG exports; second, the associated constraints to growth of the garments sector; and third, to highlight some of the steps taken by the industry leaders in terms of policy reforms and by firms, particularly with regards to managing resources to enhance competitiveness.
\end{abstract}

\footnotetext{
* Director, Centre for Research in Economics and Business, Lahore School of Economics.

** Visiting faculty, Lahore University of Management Sciences (LUMS) and Country Director, International Growth Center (IGC).

${ }^{* * *}$ Former research assistant, Centre for Research in Economics and Business, Lahore School of Economics.

The authors wish to acknowledge the excellent research assistance provided by Maha Ikram Khan, research assistant at the Centre for Research in Economics and Business, Lahore School of Economics.
} 
Keywords: Pakistan, exports, textiles, garments, international trade, growth, global value chain.

JEL classification: F10, F13, L10, L25, L50, L60, L67, O10, O14.

\section{Introduction}

The textiles and garments (T\&G) sector accounts for 48 percent of Pakistan's total exports, 30 percent of value-added in large-scale manufacturing, and 40 percent of industrial employment (Table 1). The sector is expected to continue doing well, given that Pakistan was recently granted GSP-plus status by the European Union (EU), which has opened up a large market for the country's T\&G exports. Furthermore, rising labor costs in China and the increasing technological sophistication of its manufactured exports are likely to reduce the Chinese share (about 40 percent in 2012) of the world garments market. ${ }^{1}$ This will create an opportunity for other T\&G exporters, including Pakistan, to expand their share of the market.

Additionally, as incomes rise in the large, fast-growing economies of China and India, their demand for T\&G will likely rise in tandem. This will further expand the sector's export potential for Pakistan if it builds on its close economic and political ties with the former and common overland border with the latter. Several recent developments thus point to the continued-even rising-importance of the $T \& G$ sector in expanding exports and employment in Pakistan over the next five to ten years. However, we argue that, for the sector to realize its potential, policies that shape the incentive structure facing the industry need to be realigned.

\footnotetext{
${ }^{1}$ According to Lin (2011, pp. 29-30), "China has already seen rapid growth in wages. Manufacturing wages rose from just over $\$ 150$ a month in 2005 to around $\$ 350$ in 2010. [It is likely that] China's real wages will approach $\$ 1,000$ a month within a decade." He continues, pointing out that "China will have to follow the path of the earlier Asian 'geese' and start to relocate its labor-intensive industries to low-income countries." There are a number of indications that, in the case of the apparel industry, this process is well underway. First, almost none of the garments exporters interviewed by Nabi and Hamid (2013) said they faced much competition from China; some even said that, "China is almost out" (pp. 37-39). Second, Pakistani business publications have reported for some time that Chinese investors are looking to acquire local textiles firms: in January 2014, a major textiles group from China acquired majority shares in Masood Textile Mills, Faisalabad-probably the largest knitwear manufacturer in Pakistan (Alam, 2014). Third, according to a recent McKinsey survey, 86 percent of the chief purchasing officers in leading apparel companies in Europe and the US plan to decrease levels of sourcing in China over the next five years because of declining profit margins and capacity constraints (Berg, Hedrich, \& Tochtermann, 2012).
} 
Table 1: Economic importance of the T\&G sector

\begin{tabular}{lc}
\hline T\&G sector's share of... & Percentage share in 2011/12 \\
\hline National exports & 48 \\
Large-scale manufacturing & 30 \\
Industrial employment & 40 \\
GDP & 4 \\
Market share capitalization & 5 \\
\hline
\end{tabular}

Source: Adapted from the State Bank of Pakistan (n.d.); Pakistan, Ministry of Finance (2013); All Pakistan Textile Mills Association (2014).

This paper is divided into five sections. ${ }^{2}$ Section 2 describes the structure of the $T \& G$ sector and recent trends in $T \& G$ exports. Section 3 discusses the problems and weaknesses of the garments sector, particularly those arising from the policy environment. Section 4 explores the ways in which many garments manufacturers have successfully overcome the problems associated with Pakistan's weak industrial environment. Section 5 summarizes the recent initiatives undertaken by the Punjab government, which has made the development of this sector a key element of its industrial policy. Section 6 concludes the study.

\section{T\&G Exports: Structure and Trends}

Since independence in 1947, Pakistan has been a major producer of raw cotton: in 2012, it was the fourth largest producer, accounting for about 8 percent of the world's total cotton output (US Department of Agriculture, 2014). It is not surprising, therefore, that Pakistan has followed a cotton textiles-led industrialization strategy. The textiles chain in Pakistan consists of activities spanning cotton ginning, spinning, weaving, finished fabrics, textile made-ups (particularly towels and household linen), and garments (woven and knitted apparel). In the 1960s and 1970s, Pakistan also promoted the synthetic fiber industry by giving it fiscal incentives and a high level of protection.

Initially, the textiles-led strategy was very successful and Pakistan was among the fastest growing economies in the world in the 1960s. Except for a brief interregnum during the Bhutto government's nationalization drive and heavy industry push in the 1970s, textiles remained at the forefront of Pakistan's industrialization strategy through the 1990s. The

\footnotetext{
${ }^{2}$ The discussion on garments draws heavily on Hussain et al. (2013) and Nabi and Hamid (2013).
} 
results of this strategy are evident from the continuing importance of the $\mathrm{T} \& \mathrm{G}$ sector to the economy.

However, the industry's historical pattern of development and the resulting dominance of the spinning industry in textile policymaking as well as the presence of a highly protected synthetic fiber industry have become major constraints to the growth of the value-added components of the T\&G sector since the 1990s. To some extent, this is evident from the differential performance of $T \& G$ exports in Pakistan and Bangladesh. In 2011, Bangladesh-which does not produce any cotton and had no cotton spinning mills at the time of its separation from Pakistan in 1971-had garments exports of almost US $\$ 20$ billion, i.e., about two thirds more than Pakistan's total T\&G exports that year. Although there are also other factors underlying this remarkable difference in the export performance of the two countries, we believe that the historical pattern of development of the industry has, in both cases, played an important role.

Following the end of the textiles quota regime, Pakistan's T\&G exports increased from US\$ 9.7 billion in 2005 to US\$ 11.9 billion in 2012. As a proportion of world T\&G exports, however, Pakistan's share declined from 2.46 percent in 2005 to 2.17 percent in 2012. The country's failure to benefit from the opening up of T\&G trade in 2005 is largely a result of government policies and the ensuing structure of Pakistan's T\&G sector. As Table 2 shows, Pakistan's T\&G exports are primarily either low or intermediate value-added products, which, in 2012, accounted for 69 percent of T\&G exports compared to 32 percent of world T\&G exports.

While little value is added at the spinning stage, particularly in the low- and medium-count cotton yarn that Pakistan exports, the share of yarn in its T\&G exports increased significantly between 2005 and 2012, at the expense of intermediate value-added items such as textile made-ups and manmade fiber (MMF) yarn and fabric. We also see that, while the total share of the garments sector in world $T \& G$ exports remained more or less constant at 68 percent in 2005-12, trade in knitted apparel increased far more rapidly than in woven apparel. Unfortunately, in Pakistan the reverse seems to have been the case with woven apparel exports growing more rapidly than knitted apparel. This indicates that Pakistan's strength may lie in the slower growing portion of the apparel market, which could have implications for future export growth. 
Table 2: Structure of Pakistan and world T\&G exports

\begin{tabular}{|c|c|c|c|c|c|}
\hline \multirow[b]{2}{*}{ Product } & \multirow[b]{2}{*}{ HS code } & \multicolumn{2}{|c|}{$\begin{array}{c}\text { Share of Pakistan's } \\
\text { T\&G exports (\%) }\end{array}$} & \multicolumn{2}{|c|}{$\begin{array}{l}\text { Share of world's } \\
\text { T\&G exports (\%) }\end{array}$} \\
\hline & & 2005 & 2012 & 2005 & 2012 \\
\hline \multicolumn{6}{|l|}{ Low value-added } \\
\hline Cotton yarn & $5204-07$ & 12.6 & 18.9 & 2.4 & 2.7 \\
\hline \multicolumn{6}{|c|}{ Intermediate value-added } \\
\hline Cotton fabric & $5208-12$ & 21.5 & 21.9 & 6.8 & 5.4 \\
\hline MMF yarn and fabric & 54 & 2.5 & 0.3 & 9.3 & 8.3 \\
\hline Knitted fabric & 60 & 0.7 & 0.3 & 5.1 & 5.5 \\
\hline Textile made-ups & 63 & 31.8 & 27.6 & 8.5 & 9.9 \\
\hline \multicolumn{6}{|l|}{ High value-added } \\
\hline Knitted apparel & 61 & 17.1 & 16.8 & 31.2 & 36.0 \\
\hline Woven apparel & 62 & 13.8 & 14.2 & 36.7 & 32.3 \\
\hline
\end{tabular}

Source: Authors' calculations based on data from the United Nations Commodity Trade Statistics database.

Given that this paper stresses the importance of moving up the value chain in the $T \& G$ sector, it is necessary to gain a more concrete idea of why that is so important. Table 3 provides data on the average export price per $\mathrm{kg}$ for the main $\mathrm{T} \& \mathrm{G}$ products exported by Pakistan. In many cases, at the aggregate product level the quantity in terms of weight is not available, which is why the table provides the average price per $\mathrm{kg}$ for the most important items at the HS 6-digit level in that product category. ${ }^{3}$

Starting with $1 \mathrm{~kg}$ of cotton with a value of US\$2, the spinning stage adds about US\$ 1 in value; the weaving stage adds another US\$ 3.5-5 and the finishing of the fabric can add as much as US\$ 6 (as seen from the difference in value between unbleached and dyed twill). However, converting $1 \mathrm{~kg}$ of fabric into garments can add US\$20-25 (allowing for 5 percent in wasted fabric and an additional 10 percent of the garment's value for the cost of trimmings and accessories). Since spinning is the most capital-intensive industry in the T\&G sector, followed by weaving, and garment manufacture is the most labor-intensive, the ratios in terms of the number of jobs created per kilogram at each stage probably increase even more sharply. These numbers give some idea of the impact on export earnings and job creation if Pakistan was able to move up the value chain in the $T \& G$ sector.

\footnotetext{
${ }^{3}$ Since quantity in terms of weight is not reported for 2012, we have used data for 2013 in Table 3. However, for comparison, the aggregate mean unit values per item for garments are provided for both 2012 and 2013: we can see there is no significant difference between the two years.
} 
Table 3: MUV per kg of Pakistan's major T\&G export items

\begin{tabular}{|c|c|c|c|c|c|}
\hline \multirow{2}{*}{$\begin{array}{l}\text { HS } \\
\text { code }\end{array}$} & \multirow[b]{2}{*}{ Product and description } & \multirow{2}{*}{$\begin{array}{l}\text { Product/item* } \\
\text { share, } 2013\end{array}$} & \multirow{2}{*}{$\begin{array}{l}\text { MUV (\$) } \\
\text { in } 2012\end{array}$} & \multicolumn{2}{|c|}{ MUV (\$) in 2013} \\
\hline & & & & Per item & Per kg \\
\hline $5204-07$ & Cotton yarn & 18 & Per kg & & \\
\hline 520511 & $\begin{array}{l}\text { Single yarn of uncombed } \\
\text { fibers }(<14 \text { metric no.) }\end{array}$ & 7 & 2.77 & & 2.76 \\
\hline 520512 & $\begin{array}{l}\text { Single yarn of uncombed } \\
\text { fibers ( } 14-43 \text { metric no.) }\end{array}$ & 64 & 2.91 & & 2.93 \\
\hline 520532 & $\begin{array}{l}\text { Multiple yarn of uncombed } \\
\text { fibers ( } 14-43 \text { metric no.) }\end{array}$ & 9 & 3.22 & & 3.26 \\
\hline $5208-12$ & Cotton fabric & 22 & & & \\
\hline 520812 & Unbleached plain weave & 8 & & & 6.47 \\
\hline 520911 & Plain weave & 5 & & & 8.87 \\
\hline 520912 & Unbleached twill & 8 & & & 6.81 \\
\hline 520932 & Dyed twill & 7 & & & 12.52 \\
\hline 520942 & Denim & 18 & & & 8.27 \\
\hline 63 & Textile made-ups & 29 & & & \\
\hline 630231 & Other bed linen of cotton & 18 & 7.62 & & 7.66 \\
\hline 630260 & $\begin{array}{l}\text { Toilet and kitchen linen of } \\
\text { terry fabric, cotton }\end{array}$ & 21 & 4.50 & & 4.57 \\
\hline 61 & Knitted apparel & 17 & Per item & & \\
\hline 610332 & $\begin{array}{l}\text { Men's/boys' suits, jackets, } \\
\text { trousers of cotton }\end{array}$ & 3 & 6.37 & 6.71 & 31.73 \\
\hline 610462 & $\begin{array}{l}\text { Women's/girls' suits, } \\
\text { dresses, skirts of cotton }\end{array}$ & 2 & 4.05 & 3.49 & 29.25 \\
\hline 610510 & Men's/boys' shirts of cotton & 13 & 3.69 & 3.74 & 46.97 \\
\hline 610910 & $\begin{array}{l}\text { T-shirts, singlets, other vests } \\
\text { of cotton }\end{array}$ & 10 & 2.31 & 2.26 & 33.20 \\
\hline 62 & Woven apparel & 15 & & & \\
\hline 620342 & $\begin{array}{l}\text { Men's/boys' suits, jackets, } \\
\text { trousers of cotton }\end{array}$ & 35 & 6.67 & 6.84 & 39.17 \\
\hline 620462 & $\begin{array}{l}\text { Women's / girls' suits, } \\
\text { jackets, dresses, skirts of } \\
\text { cotton }\end{array}$ & 26 & 7.09 & 6.90 & 45.98 \\
\hline
\end{tabular}

* Product share as a percentage of total T\&G exports and item share as a percentage of the total export of that product. MUV = mean unit value.

Note: The average international price of cotton in 2012 and 2013 was \$1.97 and \$2.00, respectively (derived from National Cotton Council of America, 2014).

Source: Authors' calculations based on data from the United Nations Commodity Trade Statistics database.

In 2012, Pakistan's share of world exports of cotton yarn, cotton fabric, textile made-ups, and garments (knitted and woven apparel) was $15.3,8.8,6.1$, and 1.0 percent, respectively (Table 4). Instead of moving up 
the value chain, Pakistan seems to have moved downward in the last decade or so: in 2003, its world export share of these four product groups was 10.7, 6.0, 9.4, and 1.1 percent, respectively. At the same time, Pakistan's increasing concentration on cotton textiles can be seen from its declining world export share of MMF yarn and fabric, which was 1.9 percent in 2003 and 0.1 percent in 2012.

Immediately after the end of the textiles quota regime, Pakistan's garment exports declined; in order to reduce the impact of the elimination of quotas and adverse security environment, the government granted a 6 percent research and development (R\&D) subsidy to apparel exporters in 2005 (and subsequently to all T\&G exporters). The subsidy was withdrawn in 2008 because of a fiscal crisis. At best, it prevented a decline in T\&G exports, which, after increasing from US\$ 7.8 billion in 2003 to US\$ 9.7 billion in 2005, stagnated for the next three years. In 2008, T\&G exports began to grow once again, increasing to US\$ 11.9 billion in 2012, but the main driver of growth was cotton yarn, which contributed over 50 percent of the total increase in T\&G exports during this period (Table 4). Other products that recorded a significant increase over these four years were cotton fabric and woven apparel, both of which also increased their share of world exports of these products.

Table 4: Value of Pakistan's (PK) T\&G exports and share of world (WX) T\&G exports by major products

\begin{tabular}{|c|c|c|c|c|c|c|c|c|c|}
\hline \multirow{3}{*}{ Commodity } & \multirow{3}{*}{$\begin{array}{l}\text { HS } \\
\text { code }\end{array}$} & \multicolumn{2}{|c|}{ Exports 2003} & \multicolumn{2}{|c|}{ Exports 2005} & \multicolumn{2}{|c|}{ Exports 2008} & \multicolumn{2}{|c|}{ Exports 2012} \\
\hline & & PK & $\begin{array}{l}\text { Share } \\
\text { of WX }\end{array}$ & PK & $\begin{array}{l}\text { Share } \\
\text { of WX }\end{array}$ & PK & $\begin{array}{l}\text { Share } \\
\text { of WX }\end{array}$ & PK & $\begin{array}{l}\text { Share } \\
\text { of WX }\end{array}$ \\
\hline & & $\$ \mathrm{mn}$ & $\%$ & $\$ \mathrm{mn}$ & $\%$ & $\$ \mathrm{mn}$ & $\%$ & $\$ \mathrm{mn}$ & $\%$ \\
\hline Cotton yarn & $\begin{array}{l}5204- \\
07\end{array}$ & 979 & 10.7 & 1,221 & 12.8 & 1,215 & 10.5 & 2,250 & 15.3 \\
\hline Cotton fabric & $\begin{array}{l}5208- \\
12\end{array}$ & 1,470 & 6.0 & 2,078 & 7.8 & 2,216 & 7.8 & 2,603 & 8.8 \\
\hline MMF & 54 & 621 & 1.9 & 240 & 0.7 & 35 & 0.1 & 34 & 0.1 \\
\hline Knitted fabric & 60 & 53 & 0.3 & 67 & 0.3 & 69 & 0.3 & 36 & 0.1 \\
\hline $\begin{array}{l}\text { Textile made- } \\
\text { ups }\end{array}$ & 63 & 2,358 & 9.4 & 3,071 & 9.2 & 3,146 & 7.0 & 3,285 & 6.0 \\
\hline Knitted apparel & 61 & 1,300 & 1.3 & 1,655 & 1.3 & 1,888 & 1.1 & 2,006 & 1.0 \\
\hline Woven apparel & 62 & 1,051 & 0.9 & 1,330 & 0.9 & 1,361 & 0.8 & 1,694 & 1.0 \\
\hline $\begin{array}{l}\text { Total T\&G } \\
\text { exports }\end{array}$ & & 7,832 & 2.4 & 9,661 & 2.5 & 9,931 & 2.0 & 11,909 & 2.2 \\
\hline
\end{tabular}

Source: Authors' calculations based on data from the United Nations Commodity Trade Statistics database. 
Pakistan's T\&G exports were largely concentrated in the EU and US, with these two markets accounting for 22 and 36 percent of total T\&G exports in 2005, respectively (Table 5). With the end of the quota regime in 2005 and the post-9/11 security environment in Pakistan-with resulting long-standing travel advisories issued by the US State Department-T\&G exports to the US have fallen steadily from US\$ 3.5 billion in 2005 to US\$ 3.1 billion in 2012. In this period, exports to the EU increased from US\$ 2.1 billion in 2005 to US\$ 3.4 billion in 2012: as a result, the EU is now the largest market for Pakistan's T\&G exports, accounting for 28 percent of total exports in 2012.

Thus, it seems that an important factor in Pakistan's poor export performance in the $T \& G$ sector, particularly in value-added items (textile made-ups and garments), is the country's security situation. Had T\&G exports to the US grown at the same rate as to the EU, Pakistan's T\&G exports would have been US\$ 2.5 billion higher in 2012 than they were. ${ }^{4}$ China is Pakistan's third largest market for T\&G exports and its share has increased from 3 percent in 2005 to 15 percent in 2012. However, this increase was almost entirely due to cotton yarn exports, which accounted for 80 percent of T\&G exports to China in 2012.

Table 5: Main markets for Pakistan's T\&G exports (\%)

\begin{tabular}{llrrrrrr}
\hline & & \multicolumn{3}{c}{$\mathbf{2 0 0 5}$} & & \multicolumn{3}{c}{$\mathbf{2 0 1 2}$} \\
\cline { 3 - 8 } & \multicolumn{1}{c}{ Product } & EU & US & China & EU & \multicolumn{1}{c}{ US } & China \\
\hline 1 & Cotton yarn & 6.19 & 9.52 & 16.77 & 3.99 & 1.02 & 63.75 \\
2 & Cotton fabric* & 13.16 & 14.67 & 2.74 & 17.72 & 4.43 & 12.30 \\
3 & Textile made-ups & 25.01 & 48.49 & 0.04 & 35.27 & 40.76 & 0.70 \\
4 & Knitted apparel & 24.56 & 62.39 & 0.06 & 32.78 & 54.68 & 0.25 \\
5 & Woven apparel & 42.22 & 39.83 & 0.02 & 57.40 & 28.35 & 0.40 \\
& Total & 21.93 & 36.28 & 2.75 & 28.23 & 25.67 & 15.03 \\
\hline
\end{tabular}

* Bangladesh is also an important market for fabric-largely denim-accounting for 15.6 percent of Pakistan's fabric exports in 2012.

Source: Authors' calculations based on data from the United Nations Commodity Trade Statistics database.

The garments industry is divided into knitted and woven apparel; in 2012, Pakistan's exports of these two products were US\$ 2 billion and US\$ 1.7 billion, respectively, with the EU and the US accounting for 87 and 82 percent of knitted and woven apparel exports, respectively. The

\footnotetext{
${ }^{4}$ Garment exports would have been US\$ 4.4 billion, i.e., 20 percent higher than actual exports in 2012.
} 
knitwear industry was the first to develop due to substantial US quotas under the Multi-Fiber Arrangement, which came into effect in 1974. The US accounted for 62 percent of Pakistan's knitted apparel exports in 2005. Subsequently, the knitwear industry suffered a major setback with the end of the quota regime in 2005. This, compounded by the impact of the post9/11 security situation on exports to the US (as discussed above) compelled some of the largest firms, such as Ammar and Klass, to close down between 2006 and 2008.

The primary products exported by the woven apparel industry are cotton jeans and this is largely because the medium-staple cotton grown in Pakistan is particularly suitable for denim production; the country is also a major exporter of denim cloth. In 2005, the EU and the US were more or less equally important for Pakistan's woven apparel exporters; since then, exports to the US have declined while exports to the EU increased by over 70 percent in 2012, with the EU accounting for over 57 percent of Pakistan's woven apparel exports that year. With Pakistan having been granted GSPplus status by the EU from 2014, the latter's market share of both knitted and woven apparel exports is likely to continue to increase.

Not only is the garments industry a major contributor to exports (15 percent of Pakistan's total exports in 2012), it is also labor-intensive and probably the largest employer in the manufacturing sector. There may be a tendency to associate employment in the garments industry with visions of 'sweatshops', but the work environment is generally much better than that of most other industries in Pakistan. This is because virtually the entire output is exported, which means that the large and medium-sized garment firms have to meet the safety and social compliance standards set by international buyers. In the "post-9/11-post-textile quotas" world, Pakistan, unlike Bangladesh, has not been the country of choice for international buyers. As a result, large garment manufacturers in Pakistan have faced much stricter scrutiny and had to meet higher standards of compliance to retain or attract large buyers (both among brands such as Levis and Gap and retail chains such as Zara and JC Penney) as customers.

Jobs in the garments industry also pay better on average as the ratio of unskilled to skilled workers (mostly stitchers) is 20:80 and, according to Nabi and Hamid (2013), in 2012 the take-home monthly earnings of stitchers (PRs 15,000) were two thirds higher than the minimum wage (PRs 9,000). In addition, given the large number of skilled workers required by the garments industry and the paucity of formal training institutions in Pakistan, many large garment manufacturers run 
their own training programs. Most other firms use the apprentice route, i.e., an experienced stitcher is allowed to bring a helper who, in three to four months, acquires the necessary skills, first by observing and then performing the simpler tasks.

Finally, the garments industry probably provides employment to more female workers than any other industry in Pakistan. A number of firms we visited had set up special training programs for women and provided a pick-and-drop service for their female workers. The firms explained that the extra effort they made to hire and retain female workers was because the latter were more productive employees, better at handling fine fabrics, and more quality-conscious.

\section{Constraints to the Growth of the Garments Sector}

This section examines the key constraints to the garments industry, which include the sector's narrow base and price range, energy constraints, the poor security situation, and lack of investment in human capital.

\subsection{Product Range, Price Range, and Government Policy}

Pakistan's garment exports have a relatively narrow base, with a few products accounting for the bulk of exports. Table 6 presents data on Pakistan's exports in the ten most important products (at the HS 4-digit level that are described in Table 7) in world trade, which together account for about 74 percent of the world's garment exports. Pakistan has substantive exports (over US\$ 200 million in 2012) in only half these products. The top six products it exports account for over 78 percent of the country's garment exports but only 41 percent of the world trade in garments. This implies that Pakistani exporters are not competing in about three fifths of the world market for garments, which seems to be in line with the share of cotton and MMF in world fiber consumption. 
Table 6: Pakistan and world exports of top ten garment products, 2012

\begin{tabular}{lrrrrc}
\hline & \multicolumn{3}{c}{ World } & \multicolumn{3}{c}{ Pakistan } \\
\cline { 2 - 6 } Product & $\begin{array}{c}\text { Exports } \\
\mathbf{( m \$ )}\end{array}$ & $\begin{array}{c}\text { Share } \\
\mathbf{( \% )}\end{array}$ & $\begin{array}{r}\text { Exports } \\
\mathbf{( m \$ )}\end{array}$ & $\begin{array}{c}\text { Share } \\
\mathbf{( \% )}\end{array}$ & $\begin{array}{c}\text { Share of world } \\
\text { exports (\%) }\end{array}$ \\
\hline 6204 & 49,478 & 13.21 & 591 & 15.97 & 1.19 \\
6110 & 44,059 & 11.77 & 99 & 2.67 & 0.22 \\
6104 & 38,505 & 10.28 & 128 & 3.46 & 0.33 \\
6203 & 36,610 & 9.78 & 921 & 24.89 & 2.52 \\
6109 & 33,479 & 8.94 & 291 & 7.86 & 0.87 \\
6103 & 14,409 & 3.85 & 294 & 7.94 & 2.04 \\
6202 & 12,755 & 3.41 & 2 & 0.06 & 0.02 \\
6115 & 12,752 & 3.41 & 260 & 7.02 & 2.04 \\
6205 & 12,289 & 3.28 & 15 & 0.41 & 0.12 \\
6201 & 11,064 & 2.95 & 3 & 0.08 & 0.03 \\
$6105^{*}$ & 7,521 & 2.01 & 543 & 14.68 & 7.22 \\
Total for PK top six exports & 154,249 & 41.2 & 2,900 & 78.40 & 1.90 \\
Total garments & 374,493 & 100.00 & 3,701 & 100.00 & 0.99 \\
\hline
\end{tabular}

* Ranked 16 in importance in 2012.

Source: Authors' calculations based on data from the United Nations Commodity Trade Statistics database.

An important segment of the market in which Pakistan has a very limited presence is women's garments. For example, women's garments account for three of the ten most traded products in the world-Pakistan has substantial exports in only one of these, probably because MMF yarn and fabrics and other imported inputs (such as trimmings and accessories) are more important in the case of women's garments than men's garments.

Table 7: Leading garment products in world trade

\begin{tabular}{ll}
\hline HS code & \multicolumn{1}{c}{ Description of products in that category } \\
\hline 6103 & Men's/boys' suits, jackets, trousers, etc., knitted or crocheted \\
6104 & Women's/girls' suits, dresses, skirts, etc., knitted or crocheted \\
6105 & Men's/boys' shirts, knitted or crocheted \\
6109 & T-shirts, singlets, other vests, knitted or crocheted \\
6110 & Jerseys, pullovers, cardigans, etc., knitted or crocheted \\
6115 & Pantyhose, tights, hosiery n.e.s., knitted or crocheted \\
6201 & Men's/boys' overcoats, capes, wind-jackets, etc., woven \\
6202 & Women's/girls' overcoats, capes, wind-jackets, etc., woven \\
6203 & Men's/boys' suits, jackets, trousers, etc., not knitted \\
6204 & Women's/girls' suits, jackets, dresses, skirts, etc., woven \\
6205 & Men's/boys' shirts \\
\hline
\end{tabular}

Source: United Nations Commodity Trade Statistics database. 
Pakistan's exports are also concentrated around the lower end of the price range for the products it exports. Table 8 gives the average unit prices of Pakistan's garment exports of the most traded products in which its exports exceeded US\$ 200 million in 2012. For four of the five items listed, Pakistan's average export price is 47-58 percent of the world average export price. In only one item-men's knitted jackets and suits, which includes fleece jackets, hoodies, and tracksuits-is the average export price relatively close to the world average of 85 percent. In other words, not only are Pakistani exporters exporting a limited range of products, they are also competing at the lower end of the price range.

Table 8: Average unit value of Pakistan's top five garment exports, 2012*

\begin{tabular}{|c|c|c|c|c|}
\hline \multirow[b]{2}{*}{ Product } & \multirow[b]{2}{*}{ Pakistan exports (m\$) } & \multicolumn{2}{|c|}{ Average unit price (US\$) } & \multirow{2}{*}{$\begin{array}{l}\text { Pakistan average } \\
\text { /world average }(\%)\end{array}$} \\
\hline & & World & Pakistan & \\
\hline 6103 & 294 & 6.36 & 5.41 & 85.1 \\
\hline 6105 & 543 & 7.91 & 3.99 & 50.4 \\
\hline 6109 & 291 & 4.01 & 2.32 & 57.9 \\
\hline 6203 & 921 & 13.62 & 6.38 & 46.8 \\
\hline 6204 & 591 & 12.73 & 6.70 & 52.6 \\
\hline
\end{tabular}

* The combined export value of these five items was US\$2,640 million, i.e., 71 percent of Pakistan's garment exports.

Source: Authors' calculations based on data from the United Nations Commodity Trade Statistics database.

While the structure of Pakistan's garment exports explains why the sector has failed to expand more rapidly since the textile quotas regime ended in 2005, it also shows that there is considerable potential for export expansion both on the extensive (i.e., number of products) and intensive (i.e., export unit price) margins.

The government's poor industrial policy is an important reason for the narrow product range and low export unit value of Pakistan's garment exports. As already mentioned, government policies have aimed to protect existing firms in the T\&G industry, with two consequences. First, the spinning and weaving firms, which are the oldest and the largest in terms of investment, remain the most influential with regard to policymaking in this sector. Their influence can be gauged from the fact that, when exports of cotton yarn to China declined in 2013/14, they lobbied successfully for the imposition of regulatory import duty on cotton yarn from India despite strong opposition from the garments industry. 
Second, the existing MMF manufacturing plants, which were set up in the 1960s and 1970s as part of the government's import substitution strategy in that period, are small, high-cost producers that rely on outdated technology and require protection to survive. Government policy in this context takes the form of tariff and nontariff barriers on the import of MMF yarn and all kinds of fabric, including fine cotton, cotton-MMF mixed, pure $\mathrm{MMF}$, and technical ${ }^{5}$ fabrics.

This, on top of the country's inward-looking trade policy-reflected in the generally high duties and taxes imposed on imported materials, a nontransparent tariff structure, and a complex set of customs procedures $^{6}$ - has serious implications for the range of products exported and the price segment of the market targeted by Pakistani exporters. Besides MMF yarn and various kinds of fabric, garment manufacturers need to import trimmings and accessories, chemicals for washing, and dyes. Most of the entrepreneurs interviewed by Nabi and Hamid (2013) complained that customs procedures inflicted costly delays on meeting orders (p. 63). ${ }^{7}$ Thus, garment exporters generally limit themselves to products that do not require imported yarn, fabric, or special trimmings and accessories.

\footnotetext{
${ }^{5}$ Technical fabrics, such as odor-resistant, heat technology, and wicking fabrics (which force out moisture from perspiration but do not allow it to soak in) are a growing high-value segment of the garments market.

${ }^{6}$ Nontransparency arises from the large number of statutory regulatory orders (SROs) issued by the Federal Board of Revenue and by the finance, commerce, and other ministries concerned. These provide for concessional import duties levied on items for a particular firm, a certain category of importers, or a particular location, and may require certification by the director general of the Input Output Coefficient Organization. SROs may also restrict the import of certain items to a few firms and require a no-objection certificate from a government body (such as the Engineering Development Board); they can also be issued to levy regulatory duties on the import of certain items. Their implications for the complexity of the system and the discretionary powers they give to customs officials, considering that the items are specified at the 8-digit level of the Pakistan Custom Tariff Code, can only be imagined.

${ }^{7}$ An excellent example of how complex trade policies can prevent firms from moving up the value chain or innovating is the following incident, which was narrated to the authors by a firm owner and office bearer of the Pakistan Readymade Garments Manufacturers and Exporters Association (PRGMEA) in Karachi. A firm had an order from Walmart, which involved inserting a small gadget in a hoodie that would allow the wearer to listen to music on a smartphone or MP3 player in the pocket without earphones. The firm had imported the gadget under the Duty Tax Remission for Export framework, in which the SRO listed 492 items, including "others" that could be imported (against a post-dated check for the import duty) for re-export within two years. The customs officer concerned refused to release the gadget on the grounds that it was an electronics item, which was not on the list. It took the firm a month, and the support of the PRGMEA, to have the consignment of gadgets released. Because of the delay, the order had to be shipped by air at a substantial additional cost (Nabi \& Hamid, 2013, p. 65).
} 
As a result, given that MMF now comprises 65 percent of total fiber consumption in the world, Pakistani garment exporters are excluded from a substantial proportion of the market (Hussain et al., 2013, p. 27). Additionally, as it is the use of trimmings and accessories, special fabrics, and unusual dyeing and washing that add value to a garment, 8 Pakistani garment exporters are generally restricted to the lower end of the price range for the products they do export.

\subsection{Energy Shortages}

According to the owners and managers of garment firms, the most important constraint to the growth of production and exports in the garments sector has been the energy (electricity and natural gas) crisis (Nabi \& Hamid, 2013, p. 52). Pakistan has faced growing energy shortages since 2007; in 2012, most of the industry suffered power outages of 8 to 12 hours a day ${ }^{9}$ while the supply of natural gas was suspended for several months in the winter. Most large firms have installed generators at a substantial cost to meet their basic power needs, but small firms may not be able to afford this. This is particularly important in the case of the trimmings and accessories industry, which is dominated by small firms: delays in supplies of trimmings and accessories can affect both large and small firms. Suspended gas supplies are especially disruptive to the knitwear industry as natural gas is used to fire boilers for dyeing-a crucial component of the production cycle for knitted apparel-and the capital cost of switching to an alternative fuel source such as coal is substantial while the cost of LPG in place of natural gas can be prohibitive.

The energy crisis has had a twofold impact on the garments industry. First, it has raised the cost of production for garment manufacturers in Pakistan and thus made them less competitive. Second, it has increased uncertainty with regard to production planning by creating the possibility of delays at different stages of the production cycle over which the firm has little control. Timely delivery of an order is extremely important in the garments industry given its seasonal nature, ${ }^{10}$ and in the case of a delay, the manufacturer may have to ship the order by air. Thus, energy shortages not only impose a substantial cost on the manufacturer,

\footnotetext{
${ }^{8}$ In woven apparel, 40 percent of the in-house value-added comes from washing and finishing; in knitwear, dyeing and finishing contributes over 50 percent (Nabi \& Hamid, 2013, p. 22).

${ }^{9}$ While firms located on industrial estates received an uninterrupted power supply for eight hours a day, other firms in Punjab were subject to hour-long power outages every one or two hours throughout the day.

${ }^{10}$ For example, if an order is delayed even by a few weeks during the Christmas season, it becomes worthless to the buyer and may have to be disposed of by the manufacturer at a fraction of the price.
} 
but also erode the firm's credibility with its buyers as a dependable source. The latter has long-term implications, not only for the growth of export volume, but also for the product price range as the importance of timeliness increases as firms move up the price range. At the high end, even a few days' delay is usually not acceptable.

\subsection{Security and Country Risk Perception}

The impact of post-9/11 security concerns on aggregate garment exports, particularly to the US, has already been discussed. From the firms' perspective, security concerns (and travel advisories) manifest themselves in international buyers not coming to Pakistan. ${ }^{11}$ This has obvious implications for obtaining new orders, particularly for medium and small firms that cannot afford an overseas presence-many have complained that this leaves them entirely dependent on local buying houses and that they only receive orders during peak season when firms in Bangladesh are unable to meet the demand.

Security concerns also affect the price range in which Pakistan exporters can compete. The normal practice in the garments industry is for the employees of international buyers (i.e., from the design department during the product development stage and from the quality control department during the production stage) to spend considerable time in the country working with their counterparts in the exporting firm. Due to security concerns, these employees almost never visit Pakistan and since the importance of such interaction increases as firms move up the price range for a product, this makes it very difficult for Pakistani exporters to target the medium- to upper-end of the garments market in any product.

Poor security, political uncertainty, and the law and order situation mean that international buyers have a high country risk perception of Pakistan. As a result, they think (not incorrectly) that delays in production and shipment can occur at any time for reasons beyond the control of the exporter. ${ }^{12}$ Therefore, they generally do not include firms in Pakistan among their list of "reliable suppliers." The implications of this for Pakistani exporters include smaller orders, items that are less time-

\footnotetext{
${ }^{11}$ As one firm owner put it, "there are more buyers in the lobby of one hotel in Dhaka in Bangladesh on any given day than in all of Pakistan in a month" (Nabi \& Hamid, 2013, p. 13).

${ }^{12}$ A recent example of such unforeseen delays caused by political uncertainty was the stoppage of all intercity transport and the confiscation of all containers on the road in Punjab at the time by the government in the first ten days of August 2014. This resulted in many export shipments being delayed, damaged, or lost.
} 
sensitive and thus at the lower end of the price range, and a price discount relative to their competitors in other countries.

\subsection{Lack of Investment in Human Resources}

In Pakistan, the lack of educated and skilled workers is an important constraint to industry in general. The low level of general education in the country translates into poor trainability of the workforce and the shortage of formal vocational training institutions results in a skills gap that firms must fill themselves. Firms in the garments industry have identified two categories of workers vital to their growth: stitchers and middle management, i.e., supervisors, technicians, and engineers in the areas of production, quality control, dyeing, and washing (Nabi \& Hamid, 2013 , p. 45). Of the large firms, over 60 percent complained of a shortage of stitchers and over 85 percent reported difficulties in finding middle managers ${ }^{13}$ (ibid). Many of the large firms have formal training programs in place for stitchers and all of them train most of their middle managers. However, most firms felt that the poor quality of entry-level workers' schooling was an issue.

In some regions, labor shortages were exacerbated by other factors. For example, in Faisalabad, a number of firms pointed to the acute shortage of stitchers, which they explained as follows. Since workers are paid at a piece rate, the ongoing power outages had reduced their monthly earnings to the equivalent of 15-20 days worked in a month. As a result, many stitchers had left the labor market and turned instead to self-employment in the services sector or agriculture (Nabi \& Hamid, 2013, p. 47). In Karachi, the labor shortage was linked to the poor law and order situation, which had compelled some female workers to withdraw from the labor market or find service jobs nearer their homes. Stitchers from Punjab had moved to garment clusters in their province, particularly Lahore, where they felt it was safer (ibid).

To sum up, a number of constraints have prevented garment exports from expanding more rapidly. These have had an impact on both supply and demand, affecting all aspects of the industry, including costs, production volume, product diversity, and targeted price range. Some of these constraints-such as the security situation and country risk perception-are difficult for the government to address. Others, however, such as trade policy reforms and a demand management policy aimed at

\footnotetext{
${ }^{13}$ Small and medium firms felt the shortage of stitchers far less than large firms, but as far as the shortage of middle managers was concerned, the proportion (75 percent) was almost as high.
} 
providing the export industry (including garments) with an uninterrupted power and gas supply for eight to ten hours a day, could be implemented in the short to medium term with minimum budgetary implications.

\section{Garment Manufacturers' Response}

It seems surprising that, despite these constraints, the garments industry has continued to grow; some of its components, such as denim products, have expanded quite rapidly. The reason is that many firms have invested a great deal of capital (e.g., installing standby power generation capacity) and management resources to enhance their competitiveness. The purpose of this section is to highlight some of the steps taken by industry leaders, particularly with regard to the latter.

\subsection{Overcoming International Isolation}

Many firms are using information technology not only to improve their production planning and management, but also to overcome the constraint arising from buyers' unwillingness to travel to Pakistan because of security concerns. Some have installed electronic job tracking systems, which provide information from the time the yarn or fabric enters the firm, through each step of the production cycle to packing and until the shipment leaves the premises. This is made available online in the form of an "order tracking system" for the buyer, who while sitting in her office anywhere in the world, can check the status of her order in realtime (Nabi \& Hamid, 2013, pp. 27-29).

Some firms have provided their buyers with online access to all the CCTV cameras on the premises, allowing the latter to monitor in realtime the production area, cafeteria, etc., for compliance assurance. One of the larger knitwear firms is operating a just-in-time inventory system for its buyer-the Pakistani firm has been given access to realtime sales data for each of the buyer's stores and it automatically replenishes stocks as needed from the firm's warehouses in the US (Nabi \& Hamid, 2013, pp. 27-29).

To improve and retain access to large international buyers, another area that firms have worked on is meeting global standards for environment and social compliance. Some of the larger firms have invested in wastewater treatment plants and many of them have Worldwide Responsible Apparel Production Principles certification, which assures buyers of their compliance with socially responsible global standards for 
manufacturing and certifies that the products are produced under lawful, humane, and ethical conditions (Nabi \& Hamid, 2013, pp. 29-31).

\subsection{Moving Up the Value Chain}

To be part of the supply chain of a product in the middle to upper price range, it is essential for a firm to have own design capacity for product development and be able to ensure a quick turn-around for samples and trial orders. Most of the larger firms in the woven apparel industry have well-staffed design departments in Pakistan and a number of firms have also set up R\&D and design departments in London or Istanbul (Nabi \& Hamid, 2013, pp. 25-26). These are staffed by locally hired designers who spend half their time in Pakistan and half at the overseas office. Some firms have also invested in facilities for producing samples so that when they are given a new design, they can send out samples in less than a week. One firm has even set up a small production facility in Istanbul that manufactures and retails its products locally. This gives it a head-start on new fashion trends in Europe and if it receives a large order for one of the designs it has developed, the firm shifts production to its facility in Pakistan.

One approach adopted successfully by a number of small and medium-sized firms is to move up the price range by targeting niche markets. The products being supplied by different firms include heavy protective garments produced using denim and Kevlar for bikers, baseball and American football uniforms for teams in the US, sports uniforms (particularly rugby shirts) for schools in the UK, and fleece jackets (hoodies) for universities in the US (Nabi \& Hamid, 2013, pp. 26-27).

Another approach has been to develop the capacity to produce small orders of complex garments, such as heavily embroidered garments (Nabi \& Hamid, 2013, pp. 23-24). To add value to their garments, many of the large firms in the woven apparel industry have invested in advanced washing systems for denim jeans, many with technical expertise from Turkey. ${ }^{14}$ Some of the knitwear firms have invested in specialized equipment such as computer-controlled Jacquard knitting machines to produce patterned knitwear. A few firms have acquired Global Organic Textile Standard manufacturing certification. This requires creating a certified supply chain and, since there are few certified local suppliers, they

\footnotetext{
${ }^{14}$ In denim, most of the value addition occurs through the washing process: Turkey is a leader in this field.
} 
have to rely on imported organic cotton and other inputs (although one firm now grows its own organic cotton and gins it in its own factory).

\section{Recent Initiatives by the Punjab Government}

Employment generation is one of the key objectives of the Punjab government's development strategy: given the importance of the garments industry in the province and its employment and export potential, the government set up a working group in July 2013 to recommend measures that could help the industry realize its potential. The working group, which comprised policymakers and garment manufacturers, put forward a number of recommendations based on studies carried out by the International Growth Centre and other analytical work. The recommendations targeted a number of areas, including market access, energy, skills development, garment clusters, import policy, and customs procedures. The Punjab government accepted these recommendations and has initiated efforts to implement them.

On energy, which is a key determinant of the sector's international competitiveness but is a federal subject, the government decided to take a cluster-based approach by linking its efforts to Punjab's solar and coal power initiatives. Similarly, since import policy is under the purview of the federal government, the Punjab government's efforts in this area focus on customs procedures and facilitation by working with federal officers located in Punjab. The progress made in implementing the recommendations of the working group is discussed below.

\subsection{Market Access}

Pakistan had become eligible for duty-free export status to the EU under the new GSP-plus scheme. However, to benefit from the scheme, the country was required to ratify and give binding commitment to effectively implement 27 international conventions on human rights, political rights, labor rights, environment, narcotics control, and good governance. Although it ratified the necessary conventions, submission of the required implementation reports was delayed since they could be submitted only after the federal and four provincial governments had taken the necessary steps to address the shortcomings. The application for GSP status, supported by the completed reports, would then be evaluated by the European Commission's technical team and approved by the European Parliament. 
In the past, Pakistan had missed similar opportunities because of bureaucratic delays or failure to complete the reports and pursue the application on the diplomatic front. With this in mind, the working group, particularly its private sector members, highlighted the pending issues. The Punjab chief minister then personally guided the process to ensure the reports were submitted in time and the necessary diplomatic effort made to secure sufficient support for approval by the European Parliament. As a result of these efforts, Pakistan's application for GSP-plus status was approved in December 2013.

\subsection{Skills Development}

The Punjab Skills Development Fund (PSDF) has taken the lead in skills development for the garments sector with help from the PRGMEA, Punjab's Technical Education and Vocational Training Authority (TEVTA), and the Punjab Vocational Training Council (PVTC). A workshop hosted by the PSDF in collaboration with the PRGMEA was held in September 2013 to assess the demand for skilled workers in the garments industry.

Following the demand assessment, the PSDF launched the Skills for Garments scheme, which is designed to address skills shortages in the apparel industry, especially at the worker and middle management level. Under this scheme, the PSDF has started its first program for training over 9,000 individuals using a private provision, government-financed model. The 14 skills training providers in this program include some of the country's largest garment manufacturers (such as Crescent, Nishat, and Style), the PRGMEA's training institution, the Pakistan Readymade Garment Technical Training Institute, and public sector training institutions such as TEVTA and the PVTC.

\subsection{Customs Facilitation}

The Punjab government has facilitated meetings between garment manufacturers' representatives and the Federal Board of Revenue to discuss the former's concerns and suggestions for simplifying the import regime for garment exporters. While much remains to be done on this front, the government has succeeded in having the following recommendations of the working group implemented:

- A customs clearance facility for imports by the garments industry has been made available on a $24 / 7$ basis. 
- The Input Output Coefficient Organization (IOCO) office in Lahore has been fully staffed to provide quick approval for the import of materials by garment exporters under the Duty and Tax Remission for Exports (DTRE) scheme. ${ }^{15}$

\subsection{Developing Garment Clusters}

It is difficult for the Punjab government to address the pressing problem of power and gas outages, as energy sector policy and providers are under the federal government's purview. Therefore, it was decided to set up a model garments cluster near Lahore where existing firms could relocate or undertake expansion projects. The Quaid-e-Azam Apparel Park is being developed on over 1,500 acres near the Sheikhupura motorway interchange, $40 \mathrm{~km}$ from Lahore. The government has acquired the land, constituted a management board, and asked the Punjab Industrial Estates Development and Management Company to initiate development work. Some of the planned features of the apparel park are:

- A private sector management board

- Space for over 100 garment manufacturers and accessories suppliers

- Dedicated power plants for an uninterrupted power supply to the estate

- Common facilities such as effluent waste treatment plants, clean drinking water, and solid waste disposal

- A garments center of excellence for skills.

\section{Conclusion}

Given recent favorable developments for the industry in Pakistan and expected changes in the international trade structure of the sector, the T\&G industry could potentially play an important role in expanding Pakistan's exports. Garments manufacturing is also the least energy- and capital-intensive industrial activity and thus resonates with Pakistan's resource endowment to generate economic growth and employment. However, to fully realize its potential, garments manufacturing must move up the value chain. This requires reversing the 2003 to 2012 trend whereby the share of the lowest value-added product (cotton yarn) in Pakistan's

\footnotetext{
${ }^{15}$ Before a firm can import materials for use in the manufacture of garments for export under the DTRE scheme, it must obtain certification of the quantities to be imported from the IOCO. Previously, the IOCO office in Lahore served primarily as a drop-box and all applications were processed at the head office in Karachi. This often required making several trips to Karachi by someone from the firm and caused long delays in getting approval.
} 
T\&G exports increased by 50 percent, while the share of the highest valueadded product (knitted apparel) declined.

An important reason for the poor growth of the garments sector is that Pakistan exports a limited number of products and barely (if at all) competes in those products that account for about 60 percent of the world trade. Furthermore, Pakistani garment exports are concentrated around the lower end of the price range: the average export unit value of its main products ranges from 40 to 60 percent of the world average.

A major cause of the sector's lackluster export performance are the federal import policies and customs procedures that discourage the import of materials such as MMF yarn and fabric, technical textiles, and specialized trimmings and accessories, which exporters need in order to move up the value chain. Other constraints include the chronic energy shortages and Pakistan's poor security and country risk perception since 9/11. The impact of the latter can be judged from our estimate that garment exports would have been 20 percent higher in 2012 if exports to the US, the largest market for Pakistan in 2005, had grown at the same rate as Pakistan's exports to the EU after the end of the quota regime in 2005.

Garment manufacturers have tried to overcome the constraints arising from the energy shortages and adverse security and country risk perception by investing in power generation capacity, upgrading IT, developing design and R\&D capability, and opening up offices and warehouses in or near major markets and fashion centers. The Punjab government's focus on garments as a central plank of its industrial strategy has also helped. In areas of federal domain, Punjab has liaised with the concerned federal ministries and agencies to mitigate some of the constraints, such as market access and customs procedures. In areas that are in the provincial purview, the government has launched important initiatives such as the development of skills and garments clusters.

Given the emerging opportunities and the support of the Punjab government, growth in the export of garments-particularly from Punjab-is likely to accelerate. However, a significant bump up in the growth trajectory will only take place if import policies and customs procedures are substantially reformed. 


\section{References}

Alam, K. (2014). Buy-out: Chinese firm to acquire Masood Textile Mills. The Express Tribune. Retrieved from http:/ / tribune.com.pk/story/658771/buy-out-chinese-firm-toacquire-masood-textile-mills /

All Pakistan Textile Mills Association. (2014). Textile industry's economic contribution 2011-12 [Webpage]. Retrieved 20 August 2014, from http://www.aptma.org.pk/Pak_Textile_Statistics/tec.ASP

Berg, A., Hedrich, S., \& Tochtermann, T. (2012). Bangladesh: The next hot spot in apparel sourcing? [Webpage]. Retrieved from http://www.mckinsey.com/insights/consumer_and_retail/bang ladesh_the_next_hot_spot_in_apparel_sourcing

Hussain, S. T., Malik, K. Z., Khan, U., Faheem, A., Nabi, I., \& Hamid, N. (2013). A comparative analysis of the garments sector of Pakistan. Lahore: International Growth Center, Pakistan.

Lin, J. Y. (2011). From flying geese to leading dragons: New opportunities and strategies for structural transformation in developing countries (Policy Research Working Paper No. 5702). Washington, DC: The World Bank.

Nabi, I., \& Hamid, N. (2013). Garments as a driver of economic growth: Insights from Pakistan case studies. Lahore: International Growth Center, Pakistan.

National Cotton Council of America. (2014). Monthly prices [Database]. Available at http://www.cotton.org/econ/prices/monthly.cfm

Pakistan, Ministry of Finance. (2013). Pakistan economic survey 2012-2013. Islamabad: Author.

Punjab Skills Development Fund. (2011). Punjab Skills Development Fund [Website]. Retrieved 29 August 2014, from http:/ / www.psdf.org.pk/

State Bank of Pakistan. (n.d.). Economic data [Database]. Available at http://www.sbp.org.pk/ecodata/index2.asp\#real 
United Nations Statistics Division. (2014). UN comtrade [Database]. Available at http:/ /comtrade.un.org/data/

US Department of Agriculture. (2014). World agricultural production [Database]. Available at http:/ / usda.mannlib.cornell.edu/MannUsda/viewDocumentInfo .do?documentID $=1860$ 